\title{
PRIORITIES FOR THE DEVELOPMENT OF THE ECONOMY OF THE USA AND SOME EUROPEAN COUNTRIES
}

\author{
Anton Stolitnii ${ }^{1}$, Vitalii Makhinchuk ${ }^{2}$
}

\begin{abstract}
The purpose of the article is to reveal the newest and priority tendencies towards formation of the directions of encouraging the development of the world economy under globalization. The subject of the research is the priorities for the development of the economy of the USA and some European countries. Methodology. On the basis of the scientific literature analysis, the current economic situation of the USA and some European countries was analyzed and the strategic priorities and goals of the world economic development were determined, as well as the dialectical method, the method of scientific abstraction and the method of system analysis were used. The studies have shown that in order to implement foreign experience there is a number of key economic problems, which impede the development of the economy. It was found that a complex structural transformation of the world economy is needed to increase the share of the high-tech and innovative sectors. Practical implication. A comprehensive analysis of the status and determinants of economic development of the USA and some European countries from the perspective of the threats and risks associated with crisis situations in the modern world was made. The basic principles of the formation and implementation of the economic development strategy based on the harmonization of strategic priorities and strategic goals of the USA and the EU were determined, as well as the need to reform the economic sector in order to build promising areas of the economy was substantiated. Value/originality. The conducted research revealed the state of development of the economic system of the USA and some European countries.
\end{abstract}

Key words: economy, economic development, innovative development, foreign experience, priorities.

JEL Classification: F36, F63

\section{Introduction}

The development of the world economy takes place against the backdrop of global challenges that affect the functioning of the mechanisms of social reproduction. At present, the world is experiencing significant global changes and transformations. The formation of a sustainable national economy is one of the main long-term goals of public policy, which requires the identification of key factors ensuring resilience that will respond to the current and future global challenges (Shtan, 2017). The global and, in particular, the European trends towards transformation of the socioeconomic and political development of the countries on the basis of new, more effective vectors of economic growth are accompanied by profound changes in the national systems of State management of regional economic development (Tomareva-Patlakhova, 2016).

As a result of the changes taking place in society, along with the positive ones, certain negative tendencies are emerging, which are significant barrier to the development of the world economy and cause

Corresponding author:

${ }^{1}$ Classical Private University, Ukraine.

${ }^{2}$ F.G. Burchak Scientific-Research Institute of Private Law and Business

of the National Academy of Law Sciences of Ukraine, Ukraine.

E-mail:makhinchuk@gestors.com.ua serious problems for economic stability in the world (Mohilevskyi, Sevruk, \& Pavlenko, 2017). Numerous examples show that economic development, high competitiveness and productivity under information economy (as opposed to industrial one) is not possible without permanent accumulation of new knowledge and effective work with the relevant information. It should be noted that the interconnection between intellectual activity and material production has become especially close due to the development of information and communication technologies, which provided an opportunity for a person to continuously generate and accumulate new immense knowledge and information (Pestova, 2014).

\section{Presentation of the main material}

In the recent decades, scientific enquiry is active in the direction of identifying the tools to stimulate the development of the national economy. The ideas of Keynesian, under which the system of market relations is not perfect, the economic growth and the maximum 
possible employment of resources are ensured by active State intervention in socio-economic processes by the use of governmental tools, are the most important in this sense. These are primarily direct public spending to stimulate efficient demand, as well as the withdrawal of savings by the State through a system of taxes and loans. J. M. Keynes considered budget expenditures to be of crucial importance for investment promotion. This should help to create additional demand, which in turn leads to reduction in unemployment and inflation, to achieve full employment (Shovkun, 2017; Bilousova, 2017).

One of the most important parameters for successful implementation of the State's economic policy is the country's Global Competitiveness Index and its place in the world. Despite its conditionality, this index has many positive points, among which is an adequate level of objectivity, comparability with other countries, annual (regular) publication, constant monitoring by foreign and domestic experts (Shtan, 2017).

The representatives of the Endogenous Growth Theory School R. Lucas (1988) and P. Romer (Shultz, 1972) point out that the low level of human capital accumulation is the major obstacle to achieve economies of scale with industrialization, i.e. the economists have indicated that human capital is a source of economic growth for industrial era. However, in the context of the establishment of post-industrial society, human and intellectual forms of capital stand out as defining ones and transform into institutional forms of the existence of information or knowledge economy (Pestova, 2014).

At the current stage of the Ukraine's development as the European State, a set of strategic measures aimed at developing the economy in the context of European integration is being implemented (Yunin, Sevruk, \& Pavlenko, 2018).

Continuing our research, it is necessary to highlight some countries that have achieved significant development in the innovation sector. The United States is a country that has powerful economy, sophisticated political system, defensive and efficient army, and many other benefits. Currently, the US financial system has reached a high level of development and has become a fundamental basis of the country's economy, which provides an opportunity for dynamic development and overcoming crisis phenomena (Rudenko \& Tokar, 2010).

The following methods are used as selective and direct ones for stimulating the US economic development: ensuring the availability of financial investment resources; providing technical assistance; improvement of regulation in the area of securities; simplification of registration and licensing procedures; reformation of entrepreneurship regulation schemes; formation of intellectual capital at State universities; formation of industrial clusters; creation of a favorable tax climate; improvement of entrepreneurship education system and their information support; promotion of the prestige of entrepreneurship and entrepreneurial society in general.
One of the mechanisms used by the US Office of Technology Policy to ensure industrial advance is the US Innovation Partnership Program, which is aimed to mobilize free financial resources from the US industry, academia, and public authorities at all levels for coordination of policy initiatives in innovative development (Moskalenko, 2014).

Another mechanism used by the aforementioned management in the USA is to monitor the scientific and technological policies of other countries in order to identify the national interests and competitive position of the US industry in the international innovation market and to improve its competitiveness. The main indirect method of stimulating innovation is tax credits and preferential taxation for corporations that perform State or their own R\&D programs. Venture funds have a special place in research and development funding mechanisms, so government support for venture capital is quite serious.

Venture funding is closely linked to public-private technology partnership. It is an effective selective method for stimulating the country's leading industrial development. The developed countries accumulate significant financial resources through the venture funds. For example, the UK has a Partnership system, which is essentially a mechanism for co-existing risky knowledge-intensive projects (Moskalenko, 2014).

Today, Germany is characterized by economic stability, high standards of living, great achievements in the international banking market and other areas where the country has traditionally been a leader (Tkachenko \& Stusenko, 2011).

The Republic of France is no less financially developed today. The latter is one of the leading Western countries, ranking the seventh among other countries in the world in terms of economic development. The participation of France in the "common market" has revealed pros and cons of its economy, resulting from the fact that the country had been developing in "greenhouse" conditions of customs protectionism and through the exploitation of large colonial possessions for a long period of time (Vynohradnia, 2013).

In particular, the "Strategy for Poland" developed by the Polish Minister of Finance G. Kolodko (2014) states that the economy should be considered as public, social and market one. To implement the strategy, an economic program of market-building market reforms has been developed. The authors of the reform suggested that the program should have been implemented through the prism of a specific triangle. The first strategic "top" of the economic reform program was the "values", which are the foundation of society and economic activity.

Japan's current position in the world economy is the result of its economic development in the second half of the XX century. The country's economy is aimed at production and is one of the most powerful in the world and the largest in Asia, despite the fact that it is heavily 
dependent on supplies of raw materials from other countries due to lack of natural resources. Besides, Japan created a specific economic model with a unique system of management and organization of the production process, which covers the micro- and macroeconomic levels of development, which allowed it to move from the feudal system to the highly developed countries in relatively short period of time (Ziunkin, 2003).

By 2020, there will be an evolution of the European Union with the transition from the prevailing territorial enlargement policy to the internal regulation and greater integration policy. The recent enlargement of the EU has led to a significant increase in the heterogeneity of its internal structure, due to the significant increase in differences not only in the levels of socio-economic development but also in the institutional features of the participating countries. Understanding of these differences leads to an increase in the rejection of the further expansion of the functions of the EU communitarian bodies and, consequently, to the blocking of the necessary internal institutional reforms. This narrows the field for the further EU enlargement policy objectively, as it could be fatal to the fate of the EU itself under its old institutional mechanisms. In such circumstances, major efforts are directed towards finding the ways to enhance the cooperation between the existing Union members. However, even partial disintegration of the EU with the formation of sub-regional integration groups with different levels of intensity of interconnections (model of concentric circles) is possible (On Sustainable Development Strategy "Ukraine 2020").

Regarding the application of the principle of openness and transparency, it should be noted that the State information technology policy of the European countries includes not only the introduction of information technology into management practice, but also the establishment of cooperation between different public authorities in order to expand the national computer network and to provide information services; improvement of the State information network; implementation of electronic processing of various information flows (consumer declarations, data on export and import of goods, information on markets and industries, etc.); development of information base oflocal tax services; use of information technologies to control the environmental situation and natural resources, etc.
In most countries, special centers responsible for the implementation and improvement of information and telecommunications technologies in the activities of public authorities were established (Popovich, 1998), and it is necessary to create special financial police, which would concentrate the functions of the bodies responsible for combating economic offenses, among which there are criminal and administrative offenses, including corruption (Drozd, 2014).

\section{Conclusion}

Thus, the content of the innovation policy of the countries of the world is closely intertwined with the functioning of intellectual capital and property. The illustration of practical experience proves that only active support of the relevant State policy in the area of scientific, technical and innovative activity promotes the growth of human and intellectual capital through the process of intellectualization of labor. International business practice also shows that the creation of appropriate socio-economic conditions for the realization of intellectual capital at the company level and at the national level in general determines their prospects for maintaining international scientific and technological competitiveness. The result of active innovative policy of developing countries aimed at strengthening the national scientific and technical complex, improving the educational level of the population and involving scientific personnel in high-tech production, was the overcoming the technology gap with the developed countries (Moskalenko, 2014). Among the major factors that have influenced the scale and the nature of the aforementioned global challenges are the volatility in the foreign exchange markets; devaluation of the national currency; increase in the level of public debt; the imbalance of the food market. Ukraine's economy is characterized by susceptibility to global trends and fluctuations in the external markets. The lack of systematic mechanisms to maintain the sustainability of the national economy causes that the Ukrainian economy is significantly adversely affected by the global challenges and is unable to respond to the changes in the global economy in time. Thus, the prospects for further research in this area are justification of the mechanism for ensuring the stability of the Ukrainian economy at both national and regional level (Shtan, 2017).

\section{References:}

Bilousova, O. S. (2017). Pidvyshchennia roli derzhavnykh investytsii u modernizatsii realnoho sektoru ekonomiky Ukrainy Increasing the role of public investment in the modernization of the real sector of the economy of Ukraine]. Finance of Ukraine, 5, 63-75.

Drozd, O. Yu. (2014). Sluzhba finansovykh rozsliduvan yak orhan borotby z administratyvnymy koruptsiinymy porushenniamy [Financial Investigation Service as the body to combat administrative corruption]. Customs, 4-2 (94), 121-127.

Kolodko, Gzhehozh (2014). A quarter century of reforms. Retrieved from: http://ief.org.ua/wp-content/ uploads/2014/07/Kolodko_eng_final_for-website_PDF.pdf (accessed December 03, 2019). 
Lukas, R. E. (1988). On the Mechanics of Economic Development. Journal of Monetary Economics, 22, 3-42. Mohilevskyi, L. V., Sevruk, V. G., \& Pavlenko, S. O. (2017). Psycho-Pedagogical Training of Operating Unit Workers of National Police of Ukraine. Science and Education, 11, 120-132.

Moskalenko, O. M. (2014). Teoriia i model vyperedzhaiuchoho ekonomichnoho rozvytku $v$ systemi suspilnykh stratehichnykh potreb [Theory and model of leading economic development in the system of public strategic needs]. Kyiv: KNEU. (in Ukrainian)

On Sustainable Development Strategy "Ukraine 2020". Retrieved from: http://zakon.rada.gov.ua/laws/show/ 5/2015 (accessed December 05, 2019). (in Ukrainian)

Pestova, T. M. (2014). Dosvid zarubizhnykh krain shchodo stanovlennia ta funktsionuvannia intelektualnoi pratsi, kapitalu ta vlasnosti $\mathrm{v}$ umovakh stanovlennia ekonomiky postindustrialnoho typu [The experience of foreign countries on the formation and functioning of intellectual labor, capital and property under postindustrial economy]. Effective Economy, 3. Retrieved from: http://nbuv.gov.ua/UJRN/efek_2014_3_78 (accessed December 03, 2019). (in Ukrainian)

Popovich, M. G. (1998). Creating High-perfomance Government Organization: A Practical Guide for Public Managers. San-Francisco: Jossey-bass, $191 \mathrm{p}$.

Rudenko, Yu. M., \& Tokar, V. V. (2010). Finansovi systemy zarubizhnykh krain [Financial systems of foreign countries]. Kyiv: KNEU, 348 p. (in Ukrainian)

Schultz, T. W. (1972). Human Capital: Policy Issues and Research Opportunities, NBER Chapters, in: Economic Research: Retrospect and Prospect, Volume 6, Human Resources, 1-84, National Bureau of Economic Research, Inc.

Shovkun, I. (2017). Lokalizatsiia vyrobnytstva - svitova praktyka ta vysnovky dlia Ukrainy [Localization of production - world practice and conclusions for Ukraine]. Economy and Forecasting, 2, 31-56. (in Ukrainian)

Shtan, M. V. (2017). Napriamy derzhavnoho stymuliuvannia rozvytku ekonomiky Ukrainy [The directions of the state stimulation of economic development of Ukraine]. Economy and State, 10, 53-57. (in Ukrainian)

Tkachenko, I. V. \& Stusenko, L. A. (2011). Biudzhetno-finansova systema Yaponii [Budget and financial system of Japan]. Bulletin of Chernivtsi Trade and Economic Institute: Economic Sciences, 2(1), 92-96. (in Ukrainian)

Tomareva-Patlakhova, V. V. (2016). Priorytetni napriamy rehuliuvannia sotsialno-ekonomichnoho rozvytku Ukrainy ta yii rehioniv [The priorities of regulation of socio-economic development of Ukraine and its regions]. Investment: practice and experience, 6, 38-43. (in Ukrainian)

Vynohradnia, V.M. (2013). Osoblyvosti funktsionuvannia finansovykh system v krainakh z rynkovoiu ekonomikoiu [The features of functioning of financial systems in the market-economy countries]. University Economic Bulletin, 20(1), 199-205. (in Ukrainian)

Yunin, O., Sevruk, V., \& Pavlenko, S. (2018). Priorities of economic development of Ukraine in the context of european integration. Baltic Journal of Economic Studies, 4(3), 358-365.

Ziunkin, A. H. (2003). Finansove pravo [Financial Law]. Kyiv: MAUP, 160 p. 